\title{
TO SUBSTANTIATION OF THE LIST OF HAZARDOUS HIGHLY TOXIC CHEMICALS THAT ARE SUBJECT TO SPECIAL CONTROL REGARDING HANDLING, STORAGE, USE AND DISPOSAL Part II (arsenic compounds and cyanide)
}

\author{
M. Prodanchuk', G. Balan¹, O. Kravchuk', P. Zhminko', I. Maksymchuk ${ }^{2}$, N. Chermnykh ${ }^{1}$ \\ 'LI Medved's Research Centre of Preventive Toxicology, Food and Chemical Safety, Ministry of \\ Health, Ukraine (State Enterprise), Kyiv, Ukraine \\ ${ }^{2}$ National Police of Ukraine, Kyiv, Ukraine
}

\begin{abstract}
The Aim of the Research. To identify a group of highly toxic chemicals which over the past decades are most often used in deliberate criminal and suicidal incidents, sabotage, and terrorist act; the handling, storage, use and disposal of which must be especially carefully monitored by law enforcement agencies. In this part of the article arsenic compounds and cyanide are considered.

Materials and Methods. An analytical review of scientific publications was carried out using the abstract databases of scientific libraries Pub Med, Medline and text databases of scientific publishing houses Elsevier, Pub Med, Central, BMJ group as well as other VIP databases. Methods of systemic, comparative, and content analysis were used.

Results and Conclusions. Scientific publications that contain information on highly toxic arsenic compounds and cyanides, which pose a threat to human life and health, were analysed. Recently, in particular for more than a quarter of a century, they have become a real weapon in the hands of criminals, delinquents, and terrorists all over the world. Suicidal incidents, which also take place along with intentional criminal, terrorist, and sabotage acts, should not be concealed. Based on the analysis of the toxicity, clinical and morphological expression of intoxication when exposed to these chemicals, considering various routes of entry into the body, the need to include them in the List of hazardous highly toxic chemicals, the handling, storage, use, and disposal of which require stricter control of law enforcement agencies, is justified.
\end{abstract}

Key Words: arsenic compounds, cyanide, health risk, acute poisoning.

The Aim of the Research. To identify a group of highly toxic chemicals which over the past decades are most often used in deliberate criminal and suicidal incidents, sabotage, and terrorist act; the handling, storage, use and disposal of which must be especially carefully monitored by law enforcement agencies. In this part of the article arsenic compounds and cyanide are considered.

Materials and Methods. An analytical review of scientific publications was carried out using the abstract databases of scientific libraries Pub Med, Medline and text databases of scientific publishing houses Elsevier, Pub Med, Central, BMJ group as well as other VIP databases. Methods of systemic, comparative, and content analysis were used.

\section{Results and Conclusions}

1. Arsenic and its compounds. Arsenic (As) occurs naturally in compounds with metals or sulphur. In its pure form, it is insoluble and low toxic. But various arsenic compounds, in particular organic ones, as well as oxides and salts, are highly toxic. Moreover, the compounds of trivalent arsenic As (III) or arsenite, are more toxic than pentavalent As (V) or arsenate.

Until 90s of the last century arsenic anhydride $\left(\mathrm{As}_{2} \mathrm{O}_{3}\right)$ - arsenic trioxide, or white arsenic, was used in industry for the production of specific preparations, such as a preservative for processing leather, fur, and more widely as insecticides and rodenticides in agriculture as well as fungicides to pre-treat grain [1-5, 11-15]. The double salt of acetic acid and arsenic copper (Schweinfurt or Paris green) as well as salts of ortho arsenic acid (arsenates) i.e. arsenic sodium and arsenic calcium, which was applied as an insecticide for spraying plants, were also widely used as an insecticidefungicide to pre-treat grain. Because of the high toxicity and availability of arsenic compounds, their use in agriculture in the EU and the USA, as well as in the countries of the former Soviet Union, including Ukraine, was prohibited in the 1980s-1990s. But in a number of countries in Southeast Asia, these preparations are still being manufactured and used.

In the twentieth century, arsenic compounds were the main cause of deliberate 
homicides and suicides [1-6], as well as of mass domestic poisoning [7-9]. Poisoning of workers in the chemical industry, while manufacturing and packaging arsenic preparations in the pharmaceutical industry, processing leather and fur, preparing paints, ceramics, fireworks, as well as such preparations as insecticides (Schweinfurt greens, Davydov's preparation, etc.) took place. Workers who were unloading arsenous anhydride and agricultural workers who were pre-treating grain showed signs of poisoning. Group poisonings due to the accidental consumption of bread made of grain treated with arsenic preparations have also been described. In England, several thousand people who drank beer contaminated with arsenic were poisoned. Numerous works also describe chronic household poisoning after consumption of rainwater, which was collected from roofs painted with Paris green, as well as inhaling arsenic vapours released from paints that covered walls, wallpapers, fabrics [1-3, 12]. The toxic dose of arsenous anhydride for humans is $0,01-0,052 \mathrm{~g}$, with hypersensitivity it is $0,001 \mathrm{~g}$, the lethal dose of inorganic As compounds is 120-200 mg. Organic As compounds are 50-100 times less toxic. The half-life of inorganic compounds from the human body is approximately 48 hours. Moreover, in biological media of a patient with arsenic compounds poisoning, the concentration of As (III) is usually 20 times higher than As (V), and almost no metabolites are found. In post-mortem samples of biological media and organs, usually As (V) - arsenate and its metabolites i.e. Monomethylarsenate (MMA) and Dimethylarsenate (DMA), are detected [12-17]. If in 1990-2000 there was a decline in poisoning with arsenic compounds, then over the past two decades, an increase in deliberate and suicidal poisoning with these substances has again been observed. The content of arsenic in vivo in patients with acute poisoning reaches $40 \mathrm{mg} / 1$ [15-18]. The study of the toxicokinetics of arsenic and its metabolites in a woman with acute suicidal poisoning after administration of an arsenic-containing fungicide solution showed [15] that the As (III) content in the femoral vein was $0,6 \mathrm{mg} / \mathrm{l}$, and As (V) content was $0,04 \mathrm{mg} / \mathrm{l}$, and in the stomach there was $1,3 \mathrm{mg} / 1$ of DMA. Post-mortem examination revealed $2,3 \mathrm{mg} / 1$ of DMA at the injection site in ulnar vein, while As (III) and As (V) were not found. There was found
$28,4 \mathrm{mg} / \mathrm{kg}, 9,9 \mathrm{mg} / \mathrm{kg}$ of As (V) in the liver, while As (III) was not found. In the kidneys there was found only the content of DMA $127,0 \mathrm{mg} / \mathrm{kg}$ [15].

The toxicity of arsenic is primarily due to the blockade of thiol groups of enzyme proteins, particularly pyruvate oxidase. The selective effect of arsenic on DNA polymerase and on the pyruvate oxidase system is due to the peculiar structure of its protein molecule (the presence of two adjacent $\mathrm{SH}$-groups, with which arsenic forms stable arsenite-type compounds). In addition, arsenic contributes to the violation of the permeability of cell membranes, the accumulation of calcium in cells, mitochondrial dysfunction, the formation of oxidative stress, tissue hypoxia, and a violation of the vitamin balance. Arsenic also binds to enzymes of the Krebs tricarboxylic acid cycle and thereby disrupts oxidative phosphorylation $[6,9,11,12,15,17]$.

Clinical manifestations of acute oral and intravenous poisoning with arsenic compounds are characterized mainly by damage to the digestive, cardiovascular, nervous systems, as well as kidney, blood, and skin [1-6, 10-15, 17-20]. In 0,5-12 hours after poisoning, there appears a metallic taste in the mouth, a burning sensation in the oesophagus, difficulty with swallowing, unbearable abdominal pain, nausea, volley-like indomitable vomiting, which can last several days, diarrhoea in the form of rice water mixed with blood or bloody diarrhoea, as well as general weakness, dizziness, convulsions, collapse. Death occurs, as a rule, with a severe degree of poisoning after 624 hours, depending on the dose of arsenic compounds ingested, as a result of multiple organ failure.

In case of mild and moderate poisoning, disorders of the gastrointestinal tract develop back within a few days, a maximum of weeks, but in some cases the process gradually increases. In the most severe forms, coma develops earlier than symptoms of gastrointestinal tract damage appear and is fatal in the event of paralysis of respiratory and vasomotor centres [1-6, 15-20]. In victims who survived in presence of gastrointestinal disorders, seizures, and often epileptiform seizures, after 5-12 days from the onset of the disease, arsenic myelo-polyneuritis develops, which is characterized by severe pain syndrome, paraesthesia, sympathalgia (burning sensation 
in the legs and sharp soreness of nerve trunks). A disorder of all types of superficial sensitivity is added to this i.e. hyperesthesia changes to a sharp suppression of pain as well as tactile and temperature sensitivity up to complete anaesthesia in the distal extremities. Disorder of muscle sensitivity is often noted, which causes ataxia (arsenic pseudotabes). At the same time, patients complain of weakness in the limbs, difficulty with walking, and after a few days there are paresis of the feet and fingers, steppage. In severe cases, paralytic phenomena increase and lead to severe tetraplegia, which is accompanied by full reflection as well as muscle atrophy, which develops rapidly (most sharply in the muscles of the hands, legs, and feet). Electromyographically, a sharp decrease in the speed of the impulse along the peripheral nerves with a significant duration of latency up to the lack of nerve excitability is recorded. Often there is a forced position of the hand like a "bird's paw". Persistent pain in the extremities, accompanied by irritation of the lumbosacral roots, leads to a forced position of the body with legs pulled up to the abdomen and the formation of secondary stable contractures [3-6, 7-12, 17, 19, 20]. Histomorphological studies reveal haemorrhagic inflammation and desquamation of the epithelium of the gastrointestinal mucosa with foci of necrosis and ulcers, yellow liver dystrophy, thickening of the vessel walls, edema of the perivascular connective tissue with brown atrophy of muscle fibres in the myocardium.

In recent years, arsenic oxide (III), less often sodium arsenite, sodium arsenate and arsenic chloride (III) prevails among the causes of acute deliberate or suicidal poisoning with arsenic compounds $[9,15,20]$ Also acute poisoning with arsenous hydrogen $\left(\mathrm{AsH}_{3}\right)$ are described. Arsenous hydrogen $\left(\mathrm{AsH}_{3}\right)$ is a colourless gas, the decomposition products of which have the smell of garlic. Under industrial conditions, arsenous hydrogen is a by-product formed by the action of technical acids on metals (zinc, copper, tin, lead, bismuth, antimony, pyrite, vanadium, and gold ore, etc.) and compounds containing arsenic. Arsenic hydrogen can be released during soldering and etching metal products with acids, galvanizing iron products, melting tin alloys, filling batteries in submarines, as well as during recovery processes in the chemical industry. Arsenic hydrogen enters the body mainly through the respiratory system and is excreted in the form of arsenic in urine, faeces and sweat. This is a classic haemolytic poison that causes intravascular haemolysis with the development of anaemia, hemoglobinemia, haemoglobinuria and hyperbilirubinemia. One of the first symptoms of poisoning, which is observed already in the first hours after intoxication, is bloody urine i.e. haemoglobinuria. Massive breakdown of erythrocytes leads to the formation of a "haemolytic" kidney with haemoglobinuria, uraemia, oliguria, and anuria, which causes death $[1,20]$. It is not excluded that arsenous hydrogen can be produced in clandestine laboratories for criminal and terrorist purposes [20].

The maximum concentration for arsenic and its compounds in the air of the working area in different countries varies from 0,05 to $0,5 \mathrm{mg} / \mathrm{m}^{3}$, for arsenous hydrogen it is from 0,05 to $0,4 \mathrm{mg} / \mathrm{m}^{3}$.

In case of acute poisoning with arsenic compounds, gastric lavage with intestinal adsorbent is carried out as soon as possible after exposure. To reduce nausea morphine and magnesium sulphate are administered. As an antidote, Dimercaptopropanol (sulfactin, dicaptol, demerol, BAL) is used, which promotes the elimination of arsenic compounds in combination with proteins or enzyme proteins, forming stable, low-toxic complexes that are easily excreted by the renal route. Thanks to the free SH groups that it contains in its molecule, Dimercaptopropanol, acting competitively, can prevent the inactivation of enzymes (which have an SH group in their active centre) by toxic substances. Its dosage depends on the severity of the poisoning. In severe cases, this antidote is administered intramuscularly $3 \mathrm{mg} / \mathrm{kg}$ every 4 hours (6 injections in the first two days); in the third day $3 \mathrm{mg} / \mathrm{kg}$ every 6 hours (4 injections), starting from the fourth day for two weeks $3 \mathrm{mg} / \mathrm{kg}$ every 12 hours. In mild cases, the antidote is used at a dose of $2 \mathrm{mg} / \mathrm{kg}$ according to the same regimen. At the same time, on the first day, haemodialysis and hemosorption are effective.

In case of poisoning with arsenous hydrogen, the use of Dimercaptopropanol is ineffective. Exchange transfusion, oxygen therapy, artificial ventilation of the lungs, treatment of pulmonary edema are used. At the same time, haemodialysis and hemosorption are ineffective even on the first day after poisoning.

It should be noted that in the $90 \mathrm{~s}$, after the 
prohibition of the use of arsenic compounds in agriculture in developed countries, there was a slight decrease in the number of acute poisoning with these highly toxic substances, but in recent decades, an increase in deliberate acute poisoning of a criminal and suicidal nature is again recorded $[6,911,15,17,19,20]$. The authors attribute the increase in the number of poisonings with arsenic compounds to their greater availability through smuggling and on the Internet.

Thus, the high toxicity of arsenic compounds and the risks of their availability in Ukraine in various ways necessitate their inclusion in the List of hazardous highly toxic chemicals requiring special control over the handling, storage, use and disposal.

2. Cyanides. Cyanides are chemicals that contain a nitrile group, where a carbon atom is in a triple bond with a nitrogen atom. Cyanides can be in liquid, gaseous or salt form. This is one of the fastest-acting toxic substances that can lead to fatal poisoning in short periods of time - from a few seconds to 20-30 minutes, depending on the route of administration, dose, and exposure time, it should be noted that death occurs faster with intravenous and pulmonary administration [21-29, 32-35, 40]. Often, the presence of cyanides can be determined by the presence of a bitter almond odour, but most cyanides are odourless. Among them, hydrocyanic acid salts such as potassium cyanide $(\mathrm{KCN})$, sodium cyanide $(\mathrm{NaCN})$, ammonium cyanide $\left(\mathrm{NH}_{2} \mathrm{CN}\right)$, Ferrocyanide potassium (yellow blood salt $\left.\mathrm{K}_{4}\left[\mathrm{Fe}(\mathrm{CN})_{6}\right] 3 \mathrm{H}_{2} \mathrm{O}\right)$, which being in the air, especially at high humidity and heating easily decompose with the release of hydrocyanic acid, have high toxicity.

Hydrocyanic acid salts, mainly $\mathrm{KCN}$ and $\mathrm{NaCN}$, are used in electroplating for coating metal with copper, brass, gold, and silver, as well as for cyanidation of steel and flotation of ore. Hydrocyanic acid salts can serve as a source of formation of hydrocyanic acid (prussic acid) $(\mathrm{HCN})-$ a colourless liquid, which is very volatile and has a mild pronounced smell of bitter almonds. Hydrocyanic acid is one of the most high-potent toxic substances, which even in low concentrations can cause severe poisoning. $\mathrm{HCN}$ vapours are lighter than air, has boiling point $26^{\circ} \mathrm{C}$; easily dissolve in water, alcohol, and ether. The presence of $\mathrm{HCN}$ is determined in gases formed during by-product coke making, in a number of chemical reactions, during the production and combustion of plastics and polymer products, during the combustion of rubber, silk, and during the polishing of gold and silver products [21, 22, 34, 40, 46].

In recent decades, cyanide poisoning most often occurs during fires, both domestic and industrial, due to the widespread use of polymer, synthetic and plastic products (furniture, tableware, floor coverings such as synthetic covering, linoleum, and others, as well as clothing, carpets, etc.). In this case, the combined action of carbon monoxide and cyanide occurs. Cyanides are contained also in a number of food products, such as apricot kernels [49], lima beans, bitter almonds, and some tropical plants, which, like bitter almonds and apricot kernels, contain a cyanogenic glycoside, i.e. amygdalin, which is responsible for their toxic properties [52]. Cyanides were first educed from bitter almonds in 1800 [40]. Occupational exposure to hydrogen cyanide has been linked to the massive acute poisoning of workers during the processing of cassava in the state of Alagoas in Brazil [40]. The development of tropical ataxic neuropathy is associated with the content of cyanides in the fruits of some tropical plants [57].

In addition, cyanide poisoning is observed when cyanide-containing pesticides (insecticides, fungicides, rodenticides) are used in agriculture with violation of hygienic regulations. In Ukraine, to this day, cyanide insecticides are widely used - synthetic pyrethroids, which, if the hygiene requirements for their use are violated, often cause the development of acute poisoning in agricultural workers or amateur gardeners [30, 31].

Since the 19th century, cyanides have been widely used in murders and suicides. They are often used as a means of chemical terrorism $[45,48]$. In addition, during World War II, the Nazis used cyanide as a means of genocide in gas chambers [21, 22, 40, 54, 55]. Certain anticancer drugs contain cyanide groups. Sodium nitroprusside, used to treat coronary artery disease and hypertension, contains 5 cyanide groups per molecule. Toxic cyanide levels may be present in patients receiving long-term infusions of sodium nitroprusside [21, 22, 23, 40].

Cyanide is one of the most cytotoxic compounds. This property is explained by their high (more than oxygen) affinity with ferric iron (Fe (III)) of the iron-containing enzymes 
of the respiratory chain. By binding with $\mathrm{Fe}$ (III), cyanides inactivate these enzymes, while accompanying violations of oxygen binding with iron, impaired transportation of oxygen to tissues, and the development of acute tissue hypoxia. These enzymes include mitochondrial cytochrome oxidase a3, that leads to cellular hypoxia and apoptosis. In this case, the breathing of oxygen into the body remains adequate, but its transfer to the cells is difficult [21, 28, 29, 32, 40]. Cyanides bind to the iron ionic part of cytochrome oxidase a3, which is the last enzyme in the respiratory chain of mitochondrial electron transfer, which causes inhibition of aerobic cellular respiration and ATP synthesis, as well as excessive accumulation of hydrogen ions [21-24, 28-40]. This contributes to a shift towards anaerobic metabolism and an increase in lactic acid synthesis. An increased concentration of lactates, combined with an excess of hydrogen ions, ultimately leads to acidosis and cell death. Along with the inhibition of the enzymes of the respiratory chain, cyanides, although less, also bind to the iron of haemoglobin, which contributes to the formation of hypoxia. In addition, cyanides inhibit carbonic anhydrase, which disturbs the acidbase balance and forms metabolic acidosis. In turn, hypoxia and acidosis contribute to the development of oxidative stress. Suppression of glutamate decarboxylase increases the excitability of nerve cells, contributing to the formation of convulsive syndrome [28, 29]. All these changes at cyanide poisoning cause acute dysfunction of the cardiovascular system, respiratory arrest and quickly lead to death [28, 29].

The average lethal dose of potassium cyanide and a number of other cyanides is about $250 \mathrm{mg}$. Exposure to vapours or liquids with a high concentration of HCN or cyanide causes hyperacute poisoning, which can be fatal in seconds or minutes. The victim suddenly develops dizziness, shortness of breath, a feeling of bitter, an unpleasant taste of metal, a burning sensation in the mouth, palpitations, accompanied by coma, convulsions, the appearance of a purple tint of the mucous membranes and lips, and respiratory arrest. With a sublethal dose of cyanide, less severe clinical manifestations of poisoning develop. The first signs are bitterness in the mouth, sore throat, laryngospasm, dizziness, excessive salivation, nausea, vomiting, shortness of breath and confusion. But the severity of these mani- festations decreases a few hours after the removal of the victim from the contaminated area and the use of antidote therapy [38-44, 49-55]. The action of cyanide in low concentration in the atmospheric air causes the development of minor symptoms, in particular the appearance of a feeling of fear, headache, vomiting, shortness of breath, sometimes with the smell of bitter almonds and dizziness. In such cases, the phenomena of intoxication may disappear within a few hours after the removal of the victim from the contaminated environment. The acute form of poisoning, as a result of inhalation of a sublethal dose of cyanide, does not lead to death only if the victim is quickly withdrawn from the air pollution zone and the antidotes are administered timely. In these cases, cyanogen ions in the victim's body are freed from cytochrome oxidase, other respiratory enzymes, and haemoglobin, and as a result are converted into non-toxic compounds, i.e. thiocyanate, and are excreted in the urine. In patients with cyanide poisoning, venous blood remains excessively rich in oxygen i.e. "arterialized". The oxygen content in it approaches the oxygen content in arterial blood. This explains the bright red colour of the mucous membranes of the mouth and lips against the background of a pale face, body, and crimson limbs, which should make the doctor suspect acute poisoning with cyanide compounds and begin antidote therapy, especially with simultaneous confusion, nausea, vomiting, palpitations, the presence of mydriasis and the smell of bitter almonds while exhaling. The physician must rely on the symptoms as well as on the general clinical status of the patient.

Considering the serious consequences of cyanide toxicity and the rapid development of death, the physician should prepare to stabilize the airway, breathing and blood circulation. It should be remembered that mouth-to-mouth resuscitation is contraindicated in cyanide poisoning because of the risk to the person performing artificial respiration [23, 40]. Patients should be removed from the source of cyanide emission. Although studies showed that activated charcoal does not bind cyanide well, animal studies have shown a reduction in mortality when activated charcoal was given to victims. It is recommended to give a single dose of activated charcoal $50 \mathrm{~g}$ for adults and up to a maximum of $50 \mathrm{~g}$ for children [40]. Antidotes 
for cyanide poisoning must be given immediately. The available antidote kit for cyanide intoxication previously contained amyl nitrite, now contains sodium nitrite and sodium thiosulfate. Sodium nitrite in ampoules of $300 \mathrm{mg}$ or $10 \mathrm{mg} / \mathrm{kg}$ is administered intravenously over 3-5 minutes for adults and $0,2 \mathrm{ml} / \mathrm{kg}$ for children, not exceeding $10 \mathrm{ml}$. The dose of sodium thiosulfate is one ampoule or $12,5 \mathrm{~g}$ per $50 \mathrm{ml}$, which is administered intravenously to adults over 30 minutes, for children it is $7 \mathrm{~g}$ per $10 \mathrm{ml}$ [40]. Nitrites have become less commonly used due to their toxicity. Sodium thiosulfate binds to the mitochondrial enzyme rhodanese and facilitates the conversion of toxic cyanide into a non-toxic compound i.e. thiocyanate. However, over the past $10-15$ years, it has been shown that the priority antidote for acute cyanide poisoning, especially if the victim also has carbon monoxide poisoning, is hydroxy cobalamin [50-54]. Its use is based on the ability of cobalt compounds to bind and detoxify cyanides [52]. The chemical name for hydroxy cobalamin, Coa [a-(5,6-dimethylbenzimidazolyl)], differs from cyanocobalamin (vitamin B12) in that the cyanide fragment is replaced by a hydroxy group. The European Medicines Agency approved an antidote containing hydroxy cobalamin, Cyanokit, in 2010 [3252]. Cyanokit consists of two vials, each containing 2,5 g of hydroxy cobalamin lyophilizate, which must be diluted in $100 \mathrm{ml}$ of normal saline. The initial dose is $5 \mathrm{~g}$ for intravenous administration over 15 minutes, if the effect is insufficient, another $5 \mathrm{~g}$ is adminis- tered [32-52]. This dose is two million times more than daily intake of vitamin $B_{12}$. Most studies describe the effectiveness of hydroxy cobalamin in cyanide poisoning, both by oral and inhalation exposure - from 40 to $71 \%$ of survivors [32-52]. The groups of patients with cyanide poisoning were $42,69,101,161,220$ and more people.

It should be noted that acute cyanide poisoning is still reported in many countries [2129, 32-57]. According to the Toxic Exposure Surveillance System (TESS) of the USA, just during 1993-2002 years 3,165 cases of cyanide exposure to humans were recorded [40]. Fire is the most common source of cyanide action in industrialized countries. According to the annual report of the Toxic Exposure Surveillance System and the Poison Control Centres, just in 2007 there were 247 cases of acute cyanide poisoning in the United States [40]. The authors emphasize that in cases of cyanide poisoning, early recognition and intervention is vital, therefore action must be taken immediately, without delaying the administration of antidotes.

Thus, considering the high fast-acting toxic effect of arsenic and cyanide compounds, the rather high prevalence of acute poisoning with a high risk of death due to untimely use of antidotes, there is a significant danger to human health and life. The potential risk of their use for criminal purposes and in terrorist acts is of particular concern. So, the handling of arsenic and cyanide compounds in Ukraine, their storage, use, and disposal require stricter control.

\section{REFERENCES}

1. Fourtes L. Arsenic poisoning. Ongoing diagnostic and social problem. Postgrad. Med. 1988;83:233-4,241-4.

2. Gerhardson L, Dahlgren E, Eriksson A, Lagerkvist BE, Lundstrom J, Nordberg GF. Fatal arsenic poisoning - a case report. Scand. J. Work Environ. Health. 1988;14:130-2.

3. Massey EW, Wold D, Heyman A. Arsenic: homicidal intoxication. South Med. J. 1984;77:848-51.

4. Poklis A, Saady JJ. Arsenic poisoning: acute or chronic? Suicide or murder? Am. J. Foren. Med. Pathol. 1990; 11:226-32.

5. Embry JH, Walls HC. Serial arsenic poisoning. Albama Med. 1990;59:4-28.

6. Bartolome B, Cordoba S, Nieto S, Fernandes-Herrera J, Garcia-Diez A. Acute arsenic poisoning: clinical and histopathological features. Br. J. Dermatol. 1999.11061109.

7. Mathieu D, Mathieu-Nolf M, Germain-Alonso M, Neviere R, Furon D, Wattel F. Massive arsenic poisoning-effect of hemodialysis and dimercaprol on arsenic kinetics, Intensive Care Med. 1992;18:47-50.
8. Joliffe DM, Budd AJ, Gwilt DJ. Massive acute arsenic poisoning. Anesthesia. 1991;46:288-90.

9. Lech T, Trela F. Massive acute arsenic poisonings. Forensic Sci. Int. 2005;151:273-7.

10. Ghariani M, Adrien ML, Raucoules M, Bayle J, Jacomet Y, Grimaud D. Intoxication suraigue a l'arsenic. Ann. Fr. Anesth. Reanim. 1991;10:304-7.

11. Quatrchomine G, Ricq O, Lapalus Ph, Jacomet Y, Ollier A. Acute arsenic intoxication: forensic and toxicologic aspects (an observation). J. Foren. Sci. 1992;37:1163-71.

12. Roy A. Old textbooks out for arsenic poisoning case. Sunday Telegraph, 28 December, 1995.

13. Heitland P, Koster HD. Comparison of different medical cases in urinary arsenic speciation by fast HPLC-ICP-MS. Int. J. Environ. Health. 2009;212:432-8.

14. Leese E, Morton J, Tan E, et al. Microlitre ICP-MS determinations of unexposed UK urinary arsenic speciation reference values. J. Anal. Toxicol. 2014;38:24-30.

15. Tournel G, Houssaye C, Humbert L, Dhorne C, et al. Acute Arsenic Poisoning: Clinical, Toxicological, 
Histopathological and Forensic Features. J. Forensic Sci. 2011;56:275-8. doi: 10.1111/j.1556-4029.2010.01581.

16. Buchet JP, Lauwerys R, Roels H. Comparison of the urinary excretion of arsenic metabolites after a single oral dose of sodium arsenite, monomethylarsonate or dimethylarsinate in man. Int. Arch. Occup. Environ. Health. 1981;48:71-9.

17. Dunkan A, Taylor A, leese E, Allen S, et al. Homicidal arsenic poisoning. Annals of Clinical Biochemistry. 2015;52(4):510-5.

18. Tietz NW, editor. Clinical guide to laboratory tests, 3rd edn. Philadelphia, PA: Saunders WB;1995.72-4.

19. Saha JC, Dikshit AK, Bandyopadhyay M. A Review of Arsenic Poisoning and its Effects on Human Health. Critical Reviews in Environmental Science end Technology. 1999;29(3):281-313.

20. Trestrail J. Criminal poisoning: an investigational guide for law enforcement, toxicologists, forensic scientists, and attorneys. Clifton: Humana Press, 2007.

21. Morocco AP. Cyanides. Crit Care Cline. 2005;691-705.

22. Kerns W, Isom G, Kirk MA. Cyanide and hydrogen sulfide. In: Goldfrank LR, Flomenbaum NE, Lewin NA, Howland MA, Hoffman RS, Nelson LS, (eds.). Goldfrank's Toxicologic Emergencies New York, NY: McGraw-Hill; 2002: 1498-510.

23. Nelson L. Acute cyanide toxicity: mechanismis and manifestations. J Emerg Nurs. 2006;32:8-11.

24. Hamel J. A review acute cyanide poisoning with treatment update. Crit Care Nurse. 2011;30:72-82.

25. Borron SW. Recognition and treatment of acute cyanide poisoning. J Emerg Nurs. 2006;32:12-8.

26. Sodium nitrite and sodium thiosulfate (Nithiodote) [package insert]. Cangene BioPharma Inc.; 2011.

27. Shepard G, Velez LI. Role of 2009; 2923-46. in acute cyanide poisoning. Ann Pharmacother. 2008;42:661-9.

28. Baskin SI, Kelly JB, Maliner BI, Rockwood GA. Cyanide poisoning. Medical Aspects of Chemical and Biological Warfare Washington, DC: Borden Institute; 2009: 371-410.

29. Beasley DM, Glass WI. Cyanide poisoning: pathophysiology and treatment recommendations. Occup. Med. 1988;48:427-31.

30. Kharchenko OA, Balan HM, Bubalo NM. Syntetychni piretroidy: mekhanizm dii, hostri otruiennia ta viddaleni naslidky. Problemy kharchuvannia. 2013;1:29-39.

31. Balan HM, Kharchenko OA, Bubalo NM. Prychyny, struktura ta klinichni syndromy hostrykh otruien pestytsydamy $\mathrm{u}$ pratsivnykiv silskoho hospodarstva $\mathrm{v}$ umovakh yoho reformuvannia. Suchasni problemy toksykolohii, kharchovoi ta khimichnoi bezpeky. 2013;4:22-29.

32. European Medicines Agency A. Summary of the European public assessment report (EPAR). Cyanokit. [Online] 2012. Available http://www.ema.europa.eu/ema/index.jsp?curl=pages/medicines/human/medicines/000806/human_med_000731.jsp \&mid=WC0b01ac058001dl24. Accessed on $\overline{3}$ Jul 2012.

33. Borron SW, Baud FJ, Megarbane B, Bismuth C. Hydroxocobalamin for severe acute cyanide poisoning by ingestion or inhalation. Am. J. Emerg Med. 2007;25:551-558.

34. Coentrao L, Moura D. Acute cyanide poisoning among jewelry and textile industry workers. Am. J. Emerg Med. 2011;29:78-81.

35. Payen C, Combe C, Le Meur C, Gaillard Y, Pulce C, Descotes J. Lethal acute cyanide poisoning with potassium ferrocyanide. Am. J. Emerg Med. 2010;28:642.
36. Tassan H, Joyon D, Richard T, Lamaison D, Guelon D, Barakeh S. Potassium cyanide poisoning treated with hydroxocobalamin. Ann Fr Anesth Reanim. 1990;9:383-5.

37. Mannaioni G, Vannacci A, Marzocca C, Zorn AM, Peruzzi $\mathrm{S}$, Moroni F. Acute cyanide intoxication treated with a combination of hydroxocobalamin, sodium nitrite, and sodium thiosulfate. J. Toxicol Clin Toxicol. 2002;40:181-3.

38. Hon KL, Cheung KL. Pink toes and red urine: what is this poison? Hong Kong Med J. 2010;16:411-412.

39. Erdman AR. Reply to "Is hydroxocobalamin sate and effective for smoke inhalation? Searching for guidance in the haze" - in reply. Ann. Emerg Med. 2008;51:110-111.

40. Graham J, Traylor J. Cyanide toxicity. NCBI Bookshelf. A service of the National Library of Medicine, National Institutes of Health. Stat Pearls. Treasure Island (FL): Stat Pearls Publishing; 2020. Jun.

41. Fortin JL, Capellier G, Manzon C, Giocanti J, Gall O. Intraosseus administration of hydroxocobalamin in the acute treatment of cyanide poisoning. Burns. 2009;35:15-16.

42. Fortin JL, Judic-Peureux V, Desmettre T, Manzon C, Grimon D, Hostalek U, et al. Hydrogen cyanide poisoning in a prison environment: a case report. J Correct Health Care 2011;17:29-33.

43. Fortin J-L, Desmettre T, Manzon C, Judic-Peureux V, Peugeot-Mortier C, Giocanti J-P, et al. Cyanide poisoning and cardiac disorders: 161 cases. J Emerg Med. 2010;38:467-76.

44. Roderigue EJ, Gebre-Giorgis AA, Stewart DH, Feldman MJ, Pozez AL. Smoke inhalation injury in a pregnant patient: a literature review of the evidence and current best practices in the setting of a classic case. J Burn Care Res. 2012;33:624-33.

45. Ballantyne B. Chemical terrorism. General and Applied Toxicology. 3rd ed. Chichester, UK: John Wiley\&Sons; 2009; 2923-46.

46. Bryson D. Acute industrial cyanide intoxication and its treatment. Clinical and Experimental Toxicology of Cyanides. Bristol, UK: Wright, IOP Publishing; 1987; 348358.

47. Sauer SW, Keim ME. Hydroxocobalamin: improved public health readiness for cyanide disasters. Ann. Emerg Med. 2001;37:635-41.

48. Keim ME. Terrorism involving cyanide: the prospect of improving preparedness in the prehospital setting. Prehosp Disaster Med. 2006;21:56-60.

49. Akyildis BN, Kurtoglu S, Kondolot M, Tunc A. Cyanide poisoning caused by ingestion of apricot seeds. Ann Trop Paediatr. 2010;30:639-43.

50. Borron SW, Baud FJ, Barriot P, Imbert M, Bismuth C. Prospective study of hydroxocobalamin for acute cyanide poisoning in smoke inhalation. Ann. Emerg Med. 2007;49:794-801.

51. Desola J. Hydroxocobalamin, hyperbaric oxygen and cyanide poisoning. Undersa Hyperb Med. 2011;38:217-20.

52. Thompson JP, Marrs TC. Hydroxocobalamin in cyanide poisoning. Clin Toxicol. 2012;50:875-85. DOI: 10.3109/1563650.2012.742197

53. Dinh D, Rosini JM, Muller AA. Empiric Treatment of Cyanide Toxicity in an Enclosed - Space Fire Survivor. J. Emerg. Nurs. 2014;40:282-5. http://dx.doi.org/10.1016/ j.jen.2014.02.003.

54. Culnan DM, Craft-Coffman B, Bitz GH, Capek KD, Tu Y, Lineaweaver WC, Kuhlmann-Capek MJ. Carbon Monoxide and Cyanide Poisoning in the Burned Pregnant 
Patient: An Indication for Hyperbaric Oxygen Therapy. Ann. Plast. Surg. 2018;3:106-12. [PubMed: 29461288].

55. Parker-Cote JL, Rizer J, Vakkalanka JP, Rege SV, Holstege CP. Challenges in the diagnosis of acute cyanide poisoning. Clin Toxicol (Phila) 2018;56(7):609-17.

56. Zacarias CH, Esteban C, Rodrigues GL, Nascimento ES.
Occupational exposure to hydrogen cyanide during largescale cassava processing, in Alagoas State, Brazil. Cad Saude Publica. 2017;33(7). [PubMed: 29461288].

57. Netto AB, Netto CM, Mahadevan A, Taly AB, Agadi JB. Tropical ataxic neuropathy - A century old enigma. Neurol India. 2016 Nov-Dec; 64(6): 1151-9.

\section{ДО ОБІРУНТУВАННЯ ПЕРЕЛІКУ НЕБЕЗПЕЧНИХ ВИСОКОТОКСИЧНИХ ХІМІЧНИХ РЕЧОВИН, ЯКІ ПІДЛЯГАЮТЬ ОСОБЛИВОМУ КОНТРОЛЮ ЩОДО ОБІГУ, ЗБЕРІГАННЯ, ВИКОРИСТАННЯ ТА УТИЛІЗАЦІЇ Частина II (сполуки миш'яку та ціаніди) \\ М.Г. Проданчук ${ }^{1}$, Г.М. Балан ${ }^{1}$, О.П. Кравчук ${ }^{1}$, П.Г. Жмінько ${ }^{1}$, І.М. Максимчук ${ }^{2}$, Н.П. Чермних \\ ${ }^{1}$ Держкавне підприємство «Науковий центр превентивної токсикології, харчової та хімічної безпеки імені академіка Л.І. Медведя Міністерства охорони здоров'я України, м Київ, Україна ${ }^{2}$ Національна поліція України, м. Київ, Україна}

PЕЗЮМЕ. Мета. Виділити групу високотоксичних хімічних речовин, які за останні десятиліття найчастіше використовуються в умисних кримінальних та суїцидальних інцидентах, диверсійних і терористичних актах, обіг, зберігання, використання та утилізацію яких потрібно особливо прискіпливо контролювати правоохоронним органам. У даній частині статті йдеться про сполуки миш'яку та ціаніди.

Матеріали та методи. Аналітичний огляд наукових публікацій виконаний з використанням реферативних баз даних наукових бібліотек Pub Med, Medline і текстових баз даних наукових видавництв Elsevier, Pub Med, Central, BMJ group та інших VIP-баз даних. Використано методи системного, порівняльного та контент-аналізу.

Результати та висновки. Проаналізовано наукові публікації, в яких йдеться про високотоксичні сполуки миш'яку та ціаніди, які становлять загрозу життю і здоров'ю людини. Останнім часом, зокрема понад чверть сторіччя, вони стали справжньою зброєю в руках злочинців, кримінальних елементів і терористів у всьому світі. Не можна замовчувати й суїцидальні інциденти, які також мають місце поряд з умисними кримінальними, терористичними та диверсійними актами. На основі аналізу токсичності, клінічних та морфологічних проявів інтоксикації цих хімічних речовин, враховуючи різні шляхи надходження до організму, обгрунтовано необхідність внесення їх до Переліку особливо небезпечних хімічних речовин, обіг яких, зберігання, використання та утилізація потребують більш жорсткого контролю з боку правоохоронних органів. Ключові слова: сполуки миш'яку, ціаніди, ризик для здоров'я, гострі отруєння.

\section{К ОБОСНОВАНИЮ ПЕРЕЧНЯ ОПАСНЫХ ВЫСОКОТОКСИЧНЫХ ХИМИЧЕСКИХ ВЕЩЕСТВ, КОТОРЫЕ ПОДЛЕЖАТ ОСОБОМУ КОНТРОЛЮ ЗА ИХ ОБОРОТОМ, ХРАНЕНИЕМ, ИСПОЛЬЗОВАНИЕМ И УТИЛИЗАЦИЕЙ \\ Часть II (соединения мышьяка и цианиды) \\ Н.Г. Проданчук ${ }^{1}$ Г.М. Балан ${ }^{1}$, А.П. Кравчук', П.Г. Жминько ${ }^{1}$, И.Н. Максимчук, Н.П. Чермных ${ }^{1}$ \\ ${ }^{1}$ Государственное предприятие «Научный центр превентивной токсикологии, пищевой}

и химической безопасности имени академика Л.И. Медведя Министерства здравоохранения Украины», г. Киев, Украина

${ }^{2}$ Национальная полиция Украины, г. Киев, Украина.

PЕЗЮМЕ. Цель. Выделить группу высокотоксичных химических веществ, которые за последние десятилетия чаще всего используются в умышленных уголовных и суицидальных инцидентах, диверсионных и террористических актах, оборот, хранение, использование и утилизацию которых нужно особенно тщательно контролировать правоохранительным органам; в данной части статьи речь идет о соединениях мышьяка и цианидах.

Материалы и методы. Аналитический обзор научных публикаций выполнен с использованием реферативных баз данных научных библиотек Pub Med, Medline и текстовых баз данных научных издательств Elsevier, Pub Med, Central, BMJ group и других VIP-баз данных. Использованы методы системного, сравнительного и контент-анализа.

Результаты и выводы. Проанализированы научные публикации, в которых говорится о высокотоксичных соединениях мышьяка и цианидах, которые представляют угрозу жизни и здоровью человека. В последнее время, в частности более четверти века, они стали настоящим оружием в руках преступников, криминальных элементов и террористов во всем мире. Нельзя замалчивать и суицидальные инциденты, которые также имеют место наряду с умышленными уголовными, террористическими и диверсионными актами. На основе анализа токсичности, клинических и морфологических проявлений интоксикации этих химических веществ, учитывая различные пути поступления в организм, обоснована необходимость внесения их в Перечень особо опасных химических веществ, оборот которых, хранение, использование и утилизация требуют более жесткого контроля со стороны правоохранительных органов.

Ключевые слова: соединения мышьяка, иианиды, риск для здоровья, острые отравления. 